\title{
Microwave Vacuum Extraction for Rosehips Polyextracts
}

\author{
Levtrynska Yuliya ${ }^{1}$, Terziev Sergey ${ }^{2}$, Golinskaya Yana ${ }^{3}$ \\ 1. Ph.D., Assistant, Department of Processes, Equipment and Energy Management, Odessa National Academy of \\ Food Technologies, UKRAINE, Odessa, Kanatna st, 112, E-mail: levtrinska@ukr.net
}

2. Doctor of Technical Sciences, Associate Professor, Department of Processes, Equipment and Energy

Management, Odessa National Academy of Food Technologies, UKRAINE, Odessa, Kanatna st., 112, E-mail:

poem.onaft@gmail.com

3. Assistant of the Department of Commodity Studies and Expertise, Odessa National Academy of Food Technologies, UKRAINE, Odessa, Kanatna st., 112, E-mail: golinskaya.yana@gmail.com

\begin{abstract}
Extraction in microwave field in vacuum is investigated in paper. Decrease in pressure and influence of microwaves on intensification of extraction of water-and liposoluble components. Use of water extractant instead of two-phase solvent systems simplifies technological process for production of polyextracts.
\end{abstract}

Keywords - extraction, microwave assisted extraction, vacum, polyextracts, carotolin, rose hips.

\section{Introduction}

Rosehips are valuable raw materials for the production of phytopreparations and health food products. 100 grams of ripe cinnamon rose (Rosa cinnamomea L.) hip fruits contains about 2400 $\mathrm{mg}$ of vitamin $\mathrm{C}$ and carotenoids, causing bright coloration. Today, modern technologies of rosehips processing are divided into several basic stages, which include water extraction of fruits for preparation of ascorbic acid products in the Hezenko diffusers, and extraction with organic solvents of rosehip seeds and skin to obtain carotenoid preparations (carotolin) and rose oil (vitamin E). To extract liposoluble carotenoids organic solvents are used. Technology of obtaining polystracts with the two-phase systems of extractants, proposed by Kogan G.Ya., allowed to receive a convenient medical form combining water-soluble and liposoluble components [2].

The school of microwave extraction is developing in the Odessa National Academy of Food Technologies scientific school by professor O. Burdo`s group [3]. Barodiffusion effect occurring during impact of microwave field is investigated. Intensification of the process is achieved by boiling extractant in the capillaries of plant material, which forming steam bubbles, pushing the flow of components to the extract. Combined with the soluble components, water-insoluble components can also pass into the extract, for example: carotenoids. Consequently, there is a possibility of obtaining polystracts in devices with water solvent.

\section{Research results}

For the experimental researches hip fruits of cinnamon rose (Rosa cinnamomea L.), produced by "Lubnifarm" company, with humidity of $15 \%$ are selected. Extraction carried out with water solvent (distilled water). The temperature was determined by the GM320 radiation pyrometer. The measuring range is $0 \ldots 330^{\circ} \mathrm{C}$, with an error of $\pm 1.5^{\circ} \mathrm{C}$. Measurement accuracy (scale interval) is $0.1^{\circ} \mathrm{C}$. Amperage, voltage and field intensity indicators were determined using the KSP-50 measuring complex. Digital portable refractometer HI 96801, "Hanna Instruments", were used to determine concentration of the extract. Measuring range: $0 \ldots 85^{\circ}$ brix. Accuracy: $\pm 0.2^{\circ}$ brix. To determine the amount of vitamin $\mathrm{C}$ in the extract, the Thilmans titration method were used.

Extraction is carried out in a dilution installation. Main components of the extractor are: magnetron, extraction chamber, condenser, water cooler, vacuum pump.

Before the experiment rarefaction is formed in the extraction chamber with a vacuum pump. During the experiment, pressure in the extraction chamber was stabilized by adjusting power of the supplied electromagnetic energy and the heat removal system. Reverse fridge is provided for condensing evaporated solvent. The temperature regime in vacuum microwave extractor is 
regulated by the water cooling system. The water cooler consists of refrigerator, circulating pump and thermostat.

Vacuum control in the system is provided by an exemplary vacuum gauge. Supply of the electromagnetic energy is carried out by the power electronics unit at the command of control unit, which contains a timer and a power regulator. Water cooler consists of steam-compressor refrigeration machine, tank with cooling water, water temperature regulator and circulation pump, which provides the supply of cold water to the condenser.

During the experiment, magnetron power and concentration of the extract changed. Mass of rosehips for whole series of experiments was $100 \mathrm{~g}$. Ratio of solid phase and extractant is 1: 4 . Pressure in the extraction chamber was maintained in the range of $20 \ldots 40 \mathrm{kPa}$ (Fig. 1). On the basis of experimental data, we obtained the coefficient of mass transfer during extraction according to classical equation (1) [3].

$$
\beta_{e}=\frac{V_{e} \cdot 100}{F_{k} \cdot\left(X_{b}-X\right)},
$$

where $\beta_{e}$-effective coefficient of mass transfer, $V_{e}$ - volume of extract, $F_{k}$ - phase contact area, $X$ and $X_{b}$ - current and equilibrium concentration of the extract.

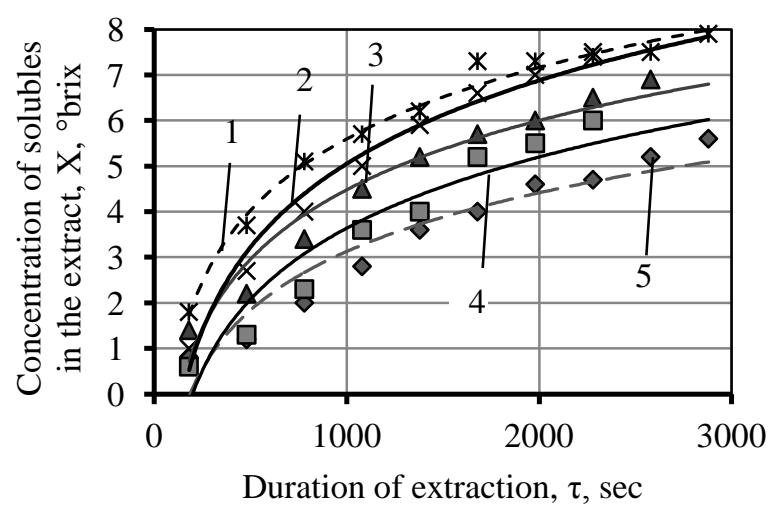

a)

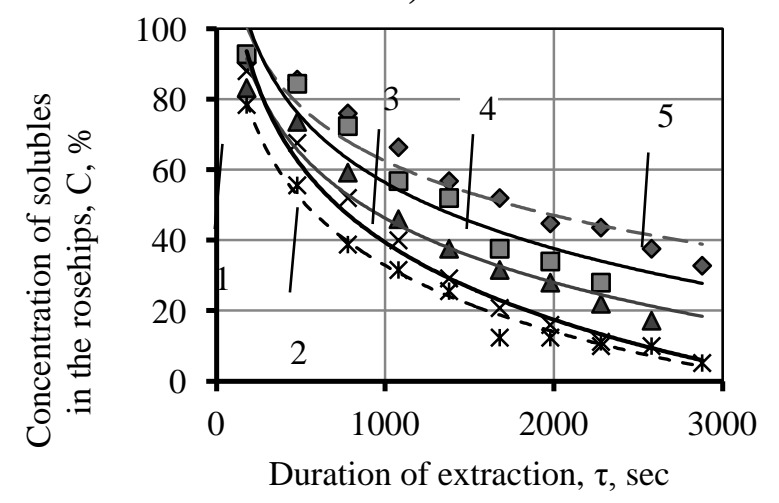

c)

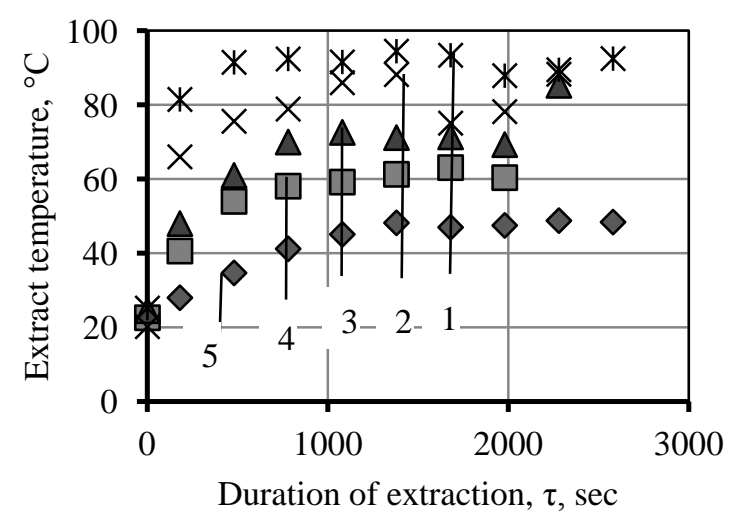

b)

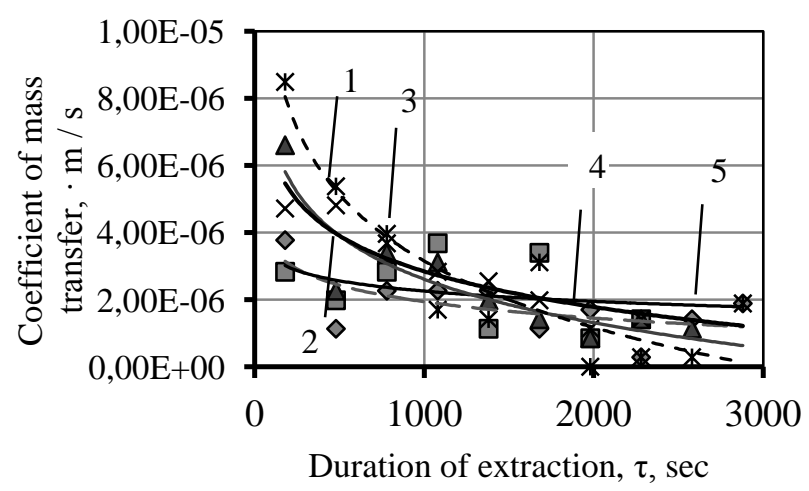

d)

Fig.1 The kinetics of extraction in the VME (a), change in temperature of the extract (b), concentration of solubles in the raw material (c), and mass transfer coefficient (d) at different intensity of the microwave field: $1-1024 \mathrm{~W} ; 2-682 \mathrm{~W} ; 3-512 \mathrm{~W} ; 4-273 \mathrm{~W} ; 5-136 \mathrm{~W}$.

Extract obtained at temperatures lower than $60^{\circ} \mathrm{C}$ (1, 2 fig. 2), according to literature data, should retain more vitamin $\mathrm{C}$, which is destroyed at higher temperatures. Content of vitamin $\mathrm{C}$ in the extract, obtained in microwave extractor compared with the one obtained in thermostat at 
temperature of about $40^{\circ} \mathrm{C}$ determined by titration method (Thilmans method). Results are presented in Table 1.

Table 1

Analysis results of ascorbic acid content in rosehips extracts

\begin{tabular}{|c|c|c|c|}
\hline Sample & $\begin{array}{c}\text { Concentration of } \\
\text { dissolved solids, } \%\end{array}$ & $\begin{array}{c}\text { Content of vitamin } \\
\mathrm{C},\end{array}$ & $\begin{array}{c}\text { Relative content of } \\
\text { vitamin } \mathrm{C}, \%\end{array}$ \\
\hline $\begin{array}{c}\text { Vacuum microwave } \\
\text { extractor }\end{array}$ & 4,2 & $430 \ldots 550$ & $10,2 \ldots 13$ \\
\hline Thermostat & 4,8 & $310 \ldots 380$ & $6,45 \ldots 7,9$ \\
\hline
\end{tabular}

Results of the experiment confirms high yield of vitamin C. In addition, content of carotenoids in the extracts were determined. This time, three samples was compared: sample obtained in thermostat, sample obtained in microwave extractor without using vacuum and sample obtained in microwave extractor under conditions of dilution. Results are presented in Table 2.

Table 2

Analysis results of carotenoid content in rosehips extracts

\begin{tabular}{|c|c|c|c|}
\hline Indicator & Thermostat & Microwave Extractor & $\begin{array}{c}\text { Vacuum microwave } \\
\text { extractor }\end{array}$ \\
\hline $\begin{array}{c}\text { Concentration of } \\
\text { dissolved solids, } \%\end{array}$ & 4,1 & 4,8 & 5,2 \\
\hline $\begin{array}{c}\text { Beta-carotene, } \\
\mathrm{mg} / 100 \mathrm{~cm}^{3}\end{array}$ & $4,120 \ldots 4,848$ & $3,946 \ldots 4,455$ & $5,824 \ldots 6,420$ \\
\hline
\end{tabular}

Results of the analysis demonstrate an increase of carotenoids yield using microwave vacuum extractor. According to the results, we can say that exactly pressure reduction has significant effect on output of carotenoids. Special conditions for reducing the viscosity and density of the extractant in conjunction with the directed action of microwave radiation contribute to intensification of the extraction of carotenoids.

\section{Conclusion}

Using of microwave effects with the system vacuuming, allowed to obtain an increased yield of not only water soluble but also oil soluble solids. The polyextract obtained with the aqueous solvent in one device should lower the price and simplify polyextract production technology.

\section{References}

[1] В. М. Мінарченко, А. Ю. Бутко, “Дослідження вітчизняного ринку лікарських засобів рослинного походження”, Фармачевтичний журнал. №. 1, С. 30-36, 2017.

[2] В. И. Чуешов, Е. В.Гладух, И. В.Сайко, О. А.Ляпунова, А. А.Сичкарь, Т. В. Крутских, Е.А. Рубан, С.В. Черняев “Технология лекарств промышленного производства“ учебник для студ. высш. учеб. завед.: перевод с укр. Яз. : в 2 ч. Ч. 1; Винница: Новая Книга, 696 с, 2014.

[3] О. Г. Бурдо, И. В. Сиротюк , Ю. Альхури, Ю. О. Левтринская, "Микроволновая энергия, как фактор интенсификации тепломассопереноса и формирования полиэкстракта", Проблемь региональной энергетики, vol. 1, is. 36, c. 58-71, 2018. DOI: 10.5281/zenodo.1217259 